\title{
Negligible isotopic fractionation of nitrogen within temperate Zostera spp. meadows
}

\author{
Douglas G. Russell, Wei Wen Wong, and Perran L. M. Cook \\ Water Studies Centre, School of Chemistry, Monash University, Clayton, 3800, Australia \\ Correspondence: Douglas G. Russell (douglas.g.russell1 @ gmail.com)
}

Received: 4 April 2018 - Discussion started: 9 April 2018

Revised: 4 October 2018 - Accepted: 23 October 2018 - Published: 4 December 2018

\begin{abstract}
Seagrass meadows form an ecologically important ecosystem in the coastal zone. The ${ }^{15} \mathrm{~N} /{ }^{14} \mathrm{~N}$ ratio of seagrass is commonly used to assess the extent to which sewagederived nitrogen may be influencing seagrass beds. There have, however, been few studies comparing the ${ }^{15} \mathrm{~N} /{ }^{14} \mathrm{~N}$ ratios of seagrass beds, their associated sediments and, of critical importance, the porewater $\mathrm{NH}_{4}^{+}$pool, which is most bioavailable. Here, we undertook a study of the ${ }^{15} \mathrm{~N} /{ }^{14} \mathrm{~N}$ ratios of seagrass tissue, sediment porewater $\mathrm{NH}_{4}^{+}$pool and the bulk sediment to elucidate the extent of any fractionating processes taking place during organic matter mineralisation and nitrogen assimilation. The study was undertaken within two coastal embayments known to receive nitrogen from a range of sources including marine, urban and sewage sources. There was close agreement between the bulk sediment $\delta^{15} \mathrm{~N}$ and seagrass $\delta^{15} \mathrm{~N}$ ( $r^{2}$ of 0.92 and mean offset of $0.9 \%$ o), illustrating a close coupling between the plant and sediment pools. The $\delta^{15} \mathrm{~N}$ of porewater $\mathrm{NH}_{4}^{+}$was strongly correlated with the $\delta^{15} \mathrm{~N}$ of both the sediment and the seagrass tissue. For both of these relationships, however, the intercept of the line was not significantly different from 0 and the slopes were not $1: 1$, reflecting an enrichment of the porewater $\mathrm{NH}_{4}^{+} \delta^{15} \mathrm{~N}$ pool relative to seagrass tissue and bulk sediment $\delta^{15} \mathrm{~N}$ at high $\delta^{15} \mathrm{~N}$ values. We suggest that nitrogen fixation is the most likely explanation for the observation that the $\delta^{15} \mathrm{~N}$ of seagrass tissue is lower than porewater $\mathrm{NH}_{4}^{+}$. Conversely, we suggest that the most likely explanation for the enrichment of porewater $\mathrm{NH}_{4}^{+}$above bulk sediment was through the preferential mineralisation of isotopically enriched algal material (nitrogen derived from sewage sources) within the sediment as $\delta^{15} \mathrm{~N}$ increased in the vicinity of a sewage treatment plant.
\end{abstract}

\section{Introduction}

Seagrass meadows are widely recognised for their high ecological value, providing a habitat for juvenile fish and stabilising sediment and sequestration of nutrients (Larkum et al., 2006; Nielsen et al., 2004). These ecosystems have been in great decline, due in part to increased nutrient run-off and eutrophication (Waycott et al., 2009). Because of the importance of nitrogen in controlling the productivity and eutrophication of coastal environments and seagrass beds, there is great interest in identifying sources of nitrogen to coastal areas.

The ratio of ${ }^{15} \mathrm{~N} /{ }^{14} \mathrm{~N}$ (hereafter referred to as $\delta^{15} \mathrm{~N}$ ) in seagrass tissue has been widely used to trace nitrogen derived from anthropogenic sources, in particular sewage into seagrass beds (McClelland and Valiela, 1998). The $\delta^{15} \mathrm{~N}$ of seagrass leaves have also been used as a proxy for nitrogen fixation by seagrass (Hirst et al., 2016; Papadimitriou et al., 2005). A recent global meta-analysis of seagrass $\delta^{15} \mathrm{~N}$ values found that latitude exerted an overwhelming influence on seagrass $\delta^{15} \mathrm{~N}$ values, with lighter values being observed in the tropics compared to temperate regions (Christiaen et al., 2014). Possible explanations for this trend included increased nitrogen fixation in tropical waters and an increased predominance of treated sewage as a source of nitrogen in temperate regions. This study highlights the fact that we still have a poor understanding of the factors that control nitrogen isotope ratios in seagrass beds.

A major pool of nitrogen available to seagrasses is ammonium $\left(\mathrm{NH}_{4}^{+}\right)$derived from within the sediment, particularly when water column nitrogen concentrations are low (McGlathery et al., 2001). Seagrasses are able to exploit this pool of bioavailable nitrogen through their ability to assimilate nutrients not just through their leaves, but also through 
their roots. Generally, this pool of $\mathrm{NH}_{4}^{+}$within the sediment is present in high concentrations, and as a consequence it is possible that ${ }^{14} \mathrm{~N}$ will be preferentially assimilated, leading to significant isotopic fractionation (Cook et al., 2015). Conversely, it is possible that the distribution of the $\mathrm{NH}_{4}^{+}$pool is highly heterogeneous, with low concentrations in the vicinity of roots which would lead to minimal fractionation during assimilation. Previous work by Papadimitriou et al. (2006) in Zostera noltii meadows found that the isotopic signature of the seagrass tissue reflected the isotopic signature of porewater $\mathrm{NH}_{4}^{+}$. This suggests that the benthic pool of nitrogen made a sizeable contribution to the nitrogen requirements of the seagrass (Papadimitriou et al., 2006). These findings are also consistent with studies in other marine sediments colonised by vegetation, such as mangroves. McKee et al. (2002) observed that the fractionation of the residual nitrogen pool in the sediment was dependent on the nitrogen (and nutrient) availability, with limited nitrogen fractionation being observed under nitrogen-limiting conditions.

In addition to the assimilation of nitrogen leading to potential isotopic fractionation of the nitrogen pool within the sediment, the breakdown (mineralisation) of organic material is another potential source of nitrogen isotope fractionation. Previous studies have found that due to the metabolic discrimination of ${ }^{14} \mathrm{~N}$ over ${ }^{15} \mathrm{~N}$ (e.g. Saino and Hattori, 1987; Altabet and Francois, 1994; Sachs and Repeta, 1999), the residual organic material can end up being isotopically enriched. Previous work by Mobius (2013), Lehmann et al. (2002) and Rooze and Meile (2016) found that in a range of marine environments isotopic fractionation was generally between $2 \%$ and $4 \%$.

Nitrogen fixation is also known to be a significant process within seagrass sediments (Welsh, 2000). Previous studies conducted in both Western Port and Port Phillip Bay (Cook et al., 2015; Russell et al., 2016) found that nitrogen fixation was responsible for the production of appreciable amounts of bioavailable nitrogen which was utilised by seagrass to meet a portion of its nitrogen requirements. It has been commonly reported that nitrogen fixation results in little isotopic fractionation (Owens, 1988), therefore in situations where nitrogen fixation is a significant process (such as in seagrass meadows), this can result in an isotopically lighter nitrogen pool. Consequently, one might expect this to lead to a lower $\delta^{15} \mathrm{~N}$ of $\mathrm{NH}_{4}^{+}$within the porewater compared to the sediment.

Given this previous research, it is clear that there are several processes that result in potentially significant fractionation of isotopes within seagrass meadows; however, few studies have explicitly investigated its occurrence or importance. Given the widespread use of $\delta^{15} \mathrm{~N}$ as a proxy for nitrogen sources and processes within seagrass, it is critical that we understand the extent of nitrogen fractionation within seagrass colonised sediments. To address this, we collected porewater samples for $\delta^{15} \mathrm{~N}$ analysis of $\mathrm{NH}_{4}^{+}$, bulk sediment and seagrass tissues to compare the $\delta^{15} \mathrm{~N}$ values from a range of seagrass beds influenced by different sources of nitrogen.

\section{Materials and methods}

\subsection{Study area}

A total of 13 sites containing Zostera muelleri (except at St. Leonards, which contained Zostera nigricaulis) were selected for this study, with 10 sites located in Port Phillip Bay and 3 sites located in Western Port (Fig. 1). Both bays are located in Victoria, Australia, and are temperate, intertidal marine embayments. Port Phillip Bay is the largest bay in Victoria and has a surface area of $\sim 1930 \mathrm{~km}^{2}$, and Western Port is located roughly $55 \mathrm{~km}$ south-east of Melbourne and has a surface area of $\sim 650 \mathrm{~km}^{2}$. The sites that were selected from Port Phillip Bay have previously been described in Cook et al. (2015) and exhibit a strong gradient in $\delta^{15} \mathrm{~N}$ from south to north, whereas the sites selected from Western Port have been previously described in Russell et al. (2016) and exhibited a range of nutrient and sediment inputs, as well as differences in areal seagrass coverage. Major sources of nitrogen to Port Phillip Bay include the rivers and drains, which contribute $\sim 1000 \mathrm{t}$ of total nitrogen $(\mathrm{TN})$ per year, and the Western Treatment Plant (WTP), which contributes 1000-1500 (Harris et al., 1996; Hirst et al., 2016). For Western Port, terrestrial sources of nitrogen from the rivers contribute $\sim 650 \mathrm{t}$ TN per year (Russell et al., 2016).

\subsection{Sample collection and preservation}

Field sampling was carried out in Western Port at intervals of $\sim 2$ months between February and November 2016, and sampling in Port Phillip Bay was carried out during August and December in 2016. Differences in the temporal aspect of the sampling regime between Western Port and Port Phillip Bay were a reflection of the logistical difficulties encountered when accessing and sampling at the different field sites. The highly tidal nature of the sites selected meant that access to some proved problematic and they were only able to be accessed sporadically. Three intact cores containing Zostera spp. (65 mm ID $\times 300 \mathrm{~mm}$ long) were obtained from each site to a sediment depth of $\sim 20 \mathrm{~cm}$. Additionally, intact samples $(n=2-4)$ of Zostera spp. were obtained from each sample site for elemental $(N)$ and stable isotope analysis $\left(\delta^{15} \mathrm{~N}\right)$. All samples were returned to Monash University within $4 \mathrm{~h}$ of sampling.

The overlying water column from the intact cores was removed using a syringe, leaving only saturated sediment. This sediment was subsequently homogenised and the porewater extracted using a combination of centrifugation and vacuum filtration. The extracted porewater was subsequently filtered through 0.45 and $0.20 \mu \mathrm{m}$ Sartorius Minisart syringe filters, and frozen until analysis, along with the samples of seagrass. This approach ignores possible depth variation in the porewater $\delta^{15} \mathrm{~N}$ values; however, previous work has shown this has minimal variation with depth (Freudenthal et al., 2001; Prokopenko et al., 2006). 


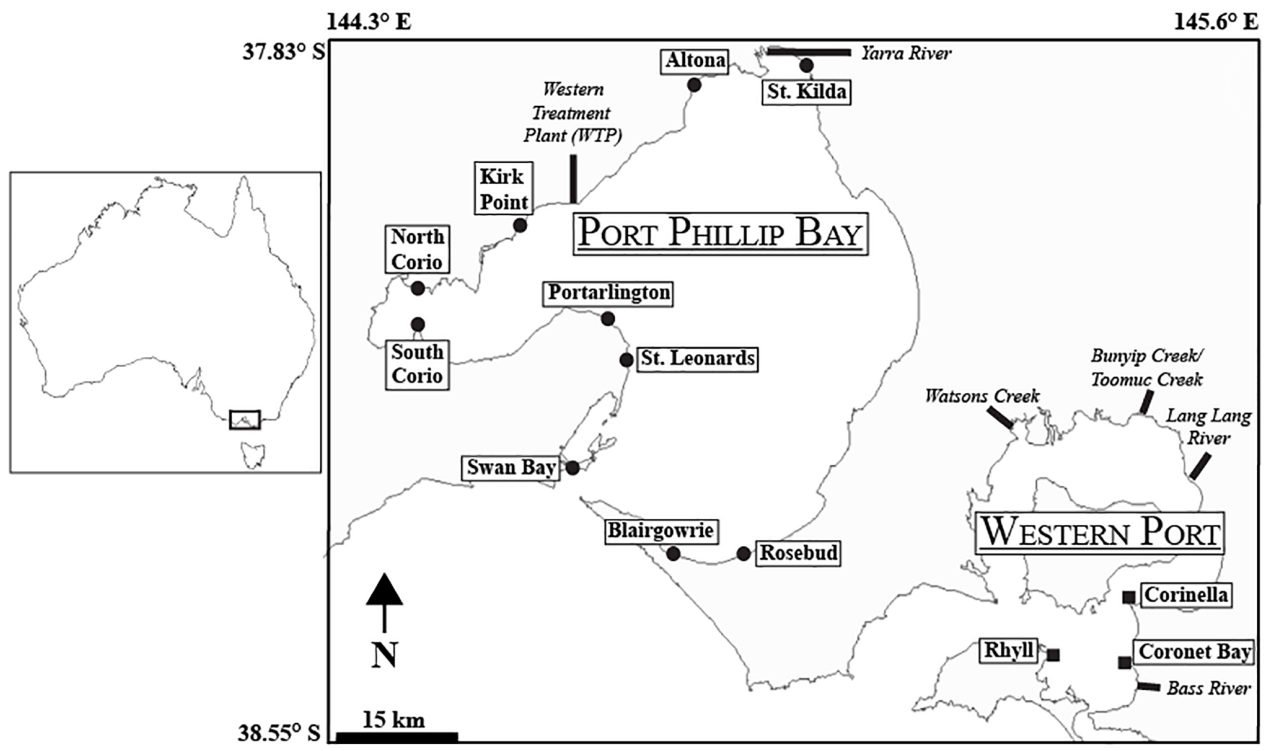

Figure 1. Western Port and Port Phillip Bay, Australia, showing the field sites. The sites marked with circles were sampled during August and December 2016, and the sites marked with squares were sampled approximately bimonthly over the period February-November 2016.

\subsection{Seagrass nitrogen isotope ratios}

Seagrass samples were collected from each site, washed by hand with deionised water to ensure that all detrital and epiphytic material was removed and then dried to a constant weight at $60^{\circ} \mathrm{C}$ for $48 \mathrm{~h}$. The seagrass samples were separated into leaves and roots/rhizomes before being pulverised using a Retsch MM400 ball mill. All analyses were carried out at Monash University on an ANCA GSL2 elemental analyzer interfaced to a Hydra 20-22 continuous-flow isotope ratio mass spectrometer (IRMS; Sercon Ltd., UK). The stable isotope data were reported in the delta notation $\left(\delta^{15} \mathrm{~N}\right)$ and relative to the isotopic ratio of atmospheric $\mathrm{N}_{2}$ $\left(R_{\text {Air }}=0.0036765\right)$. The precision of the nitrogen analysis was $\pm 0.2 \%$ (SD; $n=5)$ and $\pm 0.5 \mu \mathrm{g}(\mathrm{SD} ; n=5)$. To ensure the accuracy of the isotopic results, the following internal standards (ammonium sulfate, sucrose, gelatine and bream) were run concurrently with the seagrass samples. These internal standards have been calibrated against internationally recognised reference materials (i.e. USGS 40, USGS 41, IAEA N1, USGS 25, USGS 26 and IAEA C-6).

\subsection{Nutrient analysis $\left(\mathrm{NH}_{4}^{+}, \mathrm{FRP}\right.$ and $\left.\mathrm{NO}_{x}\right)$}

The concentration of $\mathrm{NH}_{4}^{+}$, filterable reactive phosphorous (FRP), and combined $\mathrm{NO}_{3}^{-}$and $\mathrm{NO}_{2}^{-}$(hereafter $\mathrm{NO}_{x}$ ) in the porewater at each site was determined colourimetrically (APHA, 2005) in the National Association of Testing Authorities (NATA) certified laboratory of Monash University (Water Studies Centre). Analysis of ERA-certified reference materials (lot number P2473-505) indicated the accuracy of the spectrophotometric analysis was within $2 \%$ relative error.

\subsection{Isotopic analysis of porewater $\mathrm{NH}_{4}^{+}\left(\delta^{15} \mathrm{~N}-\mathrm{NH}_{4}^{+}\right)$}

To determine the isotopic signature $\left(\delta^{15} \mathrm{~N}\right)$ of the $\mathrm{NH}_{4}^{+}$in the porewater, a slightly modified version of the ammonium diffusion method described by Brooks et al. (1989) was used. Incubations were performed in $250 \mathrm{~mL}$ Schott laboratory bottles (Schott AG, Mainz, Germany), with target concentrations of $\sim 17.9$ to $\sim 28.6 \mu \mathrm{m} \mathrm{N}-\mathrm{NH}_{4}^{+}$in a final volume $100 \mathrm{~mL}$. Any required dilutions were carried out using $\mathrm{NaCl}$ amended ultra-pure water $(\sim 35 \mathrm{ppt})$ in order to approximate in situ salinities and prevent swelling of the membranes housing the acid traps (Holmes et al., 1998). A subsample of $1 \mathrm{~mL}$ was removed from each diffusion bottle prior to the addition of the acid trap in order to determine the actual concentration of $\mathrm{N}-\mathrm{NH}_{4}^{+}$present in each sample. These samples were filtered through 0.45 and $0.20 \mu \mathrm{m}$ Sartorius Minisart syringe filters and frozen until they were analysed using the indophenol blue method (APHA, 2005). Acid traps were constructed using $4 \mathrm{~mm} \times 8 \mathrm{~mm}$ slices of pre-ashed GF/F paper (Whatman, Buckinghamshire, UK) and acidified with $20 \mu \mathrm{L}$ of $2.5 \mathrm{M} \mathrm{KHSO}_{4}$, the acidified filter paper was then housed in PTFE membranes ( $47 \mathrm{~mm}$ diameter, $10 \mu \mathrm{m}$ pore size, Merck Millipore) and crimped shut. These acid traps were added to each diffusion bottle along with $\sim 0.6 \mathrm{~g}$ of $\mathrm{MgO}$ to raise the $\mathrm{pH}$ of the solution to $\sim 10$. A series of standards were run concurrently using USGS25, USGS26 and IAEA-N1 to ensure that no mass-dependent fractionation effects were encountered. Incubations were carried out at room temperature for 3 weeks on shaker tables at $\sim 135 \mathrm{rpm}$ and the acid traps 
were then dried in a desiccator in the presence of concentrated $\mathrm{HCl}$ for 3 weeks. Afterwards, the dried filter paper was removed from the PTFE membranes and encapsulated in $12 \mathrm{~mm} \times 8 \mathrm{~mm}$ tin capsules (Sercon Ltd., UK). Samples were analysed for their isotopic signature as well as the total mass of nitrogen using the IRMS described previously. The average recovery obtained for the standards and porewater samples in this study was $100 \pm 5 \%$.

\subsection{Statistical analysis}

Linear regression analysis was carried out using GraphPad Prism 7 to investigate the relationships between variables. For all analyses, the level of significance required for the rejection of the null hypothesis was set at $p<0.05$.

\section{Results}

\subsection{Nutrient concentrations and isotopic signatures $\left(\delta^{15} \mathrm{~N}\right)$ of seagrass and porewater $\mathrm{NH}_{4}^{+}$}

Porewater concentrations of both FRP and $\mathrm{NO}_{x}$ were consistently low throughout the year in Western Port, with FRP $\leq 2 \mu \mathrm{m}$ and $\mathrm{NO}_{x} \leq 27 \mu \mathrm{m}$ (Table $\mathrm{S} 1$ in the Supplement). In contrast, the porewater concentrations of $\mathrm{NH}_{4}^{+}$were $1-2$ orders of magnitude higher (Fig. 2a), with generally higher concentrations at both Corinella and Rhyll compared to Coronet Bay. Similarly, in Port Phillip Bay, small quantities of FRP and $\mathrm{NO}_{x}$ were detected in the porewater, with the concentrations at all times $\leq 44 \mu \mathrm{M}$ and $\leq 27 \mu \mathrm{m}$ respectively (Table S2), whereas the concentration of $\mathrm{NH}_{4}^{+}$was up to an order of magnitude higher (Fig. 2b). A high spatial variation in $\mathrm{NH}_{4}^{+}$concentrations was also evident, with the sites in close proximity to terrestrial nitrogen inputs (i.e. Kirk Point and St. Kilda) consistently having the highest porewater $\mathrm{NH}_{4}^{+}$concentrations.

The $\delta^{15} \mathrm{~N}$ of seagrass in the context of this study refers to the $\delta^{15} \mathrm{~N}$ of the roots. There was, however, no significant difference between the $\delta^{15} \mathrm{~N}$ of the seagrass roots and that of the leaves (Fig. S1). The heaviest values were consistently found at both Corinella and Rhyll, which were in the closest proximity to human activities and catchment inputs, whilst the site at Coronet Bay was the furthest from these inputs and showed a correspondingly low isotopic signature. In contrast, there was appreciable variation in the isotopic signature of the seagrass in Port Phillip Bay (Fig. 2d), with values varying from $\sim 2.2 \%$ o to in excess of $16 \%$ over the course of 2016 . The highest isotopic signatures were consistently found in the northerly sites (Kirk Point, Altona and St. Kilda), and south-eastern sites (Blairgowrie and Rosebud), with all isotopic signatures $\geq 6.9 \%$. In contrast, the seagrass meadows located in the south-west of Port Phillip Bay (Swan Bay and North Corio) consistently exhibited the lowest isotopic signatures of between $2.2 \%$ and $6.4 \%$.
The isotopic signature of porewater $\mathrm{NH}_{4}^{+}$in Western Port was found to exhibit relatively little variation, with values ranging from $\sim 3.9 \%$ to $7 \%$ o throughout the course of this study (Fig. 2e). Whilst there was no evidence of significant temporal variability in the isotopic signature at each site, there was, however, an apparent north-south gradient in isotopic signatures. In general, the least isotopically enriched porewater $\mathrm{NH}_{4}^{+}$was found in the northern sites (Corinella and Coronet Bay), whilst the highest was found at Rhyll.

Unlike Western Port, appreciable spatial variation in the isotopic signature of porewater $\mathrm{NH}_{4}^{+}$was observed throughout Port Phillip Bay. The highest values of between 11.4\%o and $19.4 \%$ were consistently observed in the northern sections of the bay from Kirk Point to St. Kilda, whilst sites such as Portarlington and North Corio consistently displayed the lowest values of between $4.2 \%$ and $6.4 \%$ (Fig. 2f). The isotopic signature was found to remain reasonably constant throughout the year with the exception of St. Leonards, which displayed an appreciable decrease from winter to summer.

\subsection{Potential isotopic effects associated with vegetative assimilation and mineralisation}

An extremely strong positive and statistically significant linear correlation was observed between the isotopic signatures of seagrass and porewater $\mathrm{NH}_{4}^{+}$for all sites throughout this study (Fig. 3a; $r^{2}=0.86, p<0.001$ ), with a gradient of 0.79 (95\% CI 0.67-0.90) and a $y$ intercept of 0.09 (95\% CI $-0.97-1.1)$. This showed that there was no consistent offset in the nitrogen isotope signatures for the porewater $\mathrm{NH}_{4}^{+}$and seagrass tissue (the $y$ intercept was not significantly different from 0), but that there was an increasing difference between the seagrass tissue and the sediment porewater $\mathrm{NH}_{4}^{+}$ pool at higher $\delta^{15} \mathrm{~N}$ values, with seagrass roots being $\sim 5 \%$ less than the porewater $\mathrm{NH}_{4}^{+}$pool at the highest $\delta^{15} \mathrm{~N}$ values. A strong relationship was also observed between the isotopic signatures of sedimentary nitrogen pool and porewater $\mathrm{NH}_{4}^{+}$(Fig. 3b; $r^{2}=0.89, p<0.001$ ), with a gradient of 0.77 (95\% CI $0.67-0.88$ ), and a $y$ intercept of 0.72 (95\% CI $-0.27-1.7$ ). This showed that there was no consistent offset in the nitrogen isotope signatures of the porewater $\mathrm{NH}_{4}^{+}$and the sediment $\delta^{15} \mathrm{~N}$ (the $y$ intercept was not significantly different from 0 ), but there was an increasing difference between the sediment $\delta^{15} \mathrm{~N}$ and the sediment porewater $\mathrm{NH}_{4}^{+}$pool at higher $\delta^{15} \mathrm{~N}$ values, with the sediment $\delta^{15} \mathrm{~N}$ being $\sim 5 \%$ o less than the porewater $\mathrm{NH}_{4}^{+}$pool at the highest $\delta^{15} \mathrm{~N}$ values. Bulk sediment and seagrass $\delta^{15} \mathrm{~N}$ values were also tightly correlated with an $r^{2}$ of 0.92 (Fig. 4), with a gradient of 0.944 (95\% CI $0.84-1.05$ ) and a $y$ intercept of 0.9 (95\% CI 0.092-1.71). This showed that there was a small consistent offset of $\sim 1 \%$ o between the $\delta^{15} \mathrm{~N}$ of the seagrass and the sediment. There was no relationship between $\Delta\left(\delta^{15} \mathrm{~N}_{\text {porewater }} \mathrm{NH}_{4}^{+}\right.$-seagrass $)$and porewater $\mathrm{NH}_{4}^{+}$concentra- 


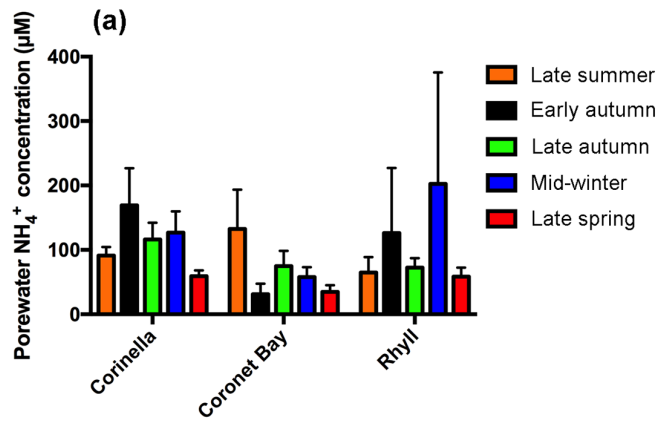

(b)

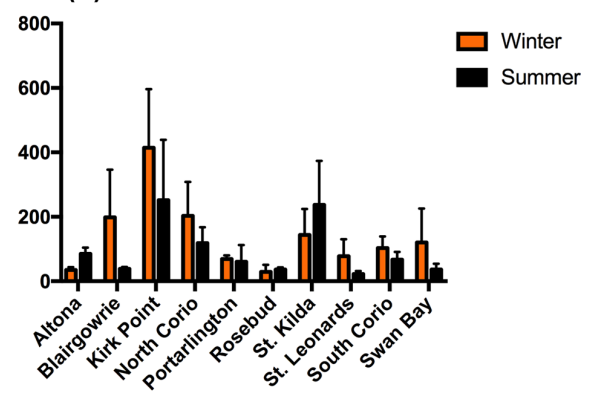

(c)

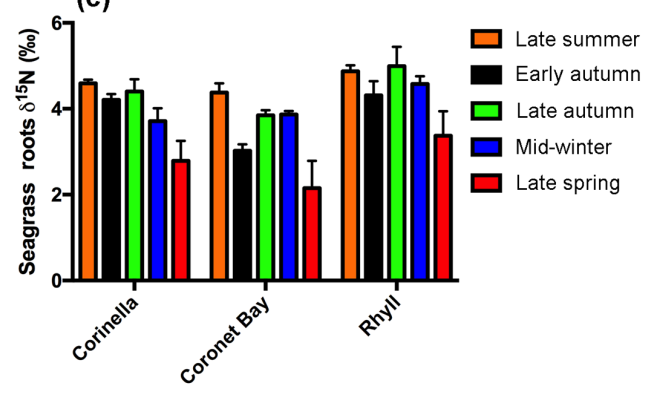

(d)

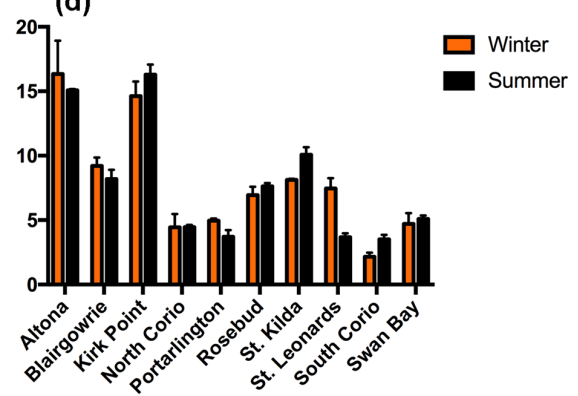

(e)
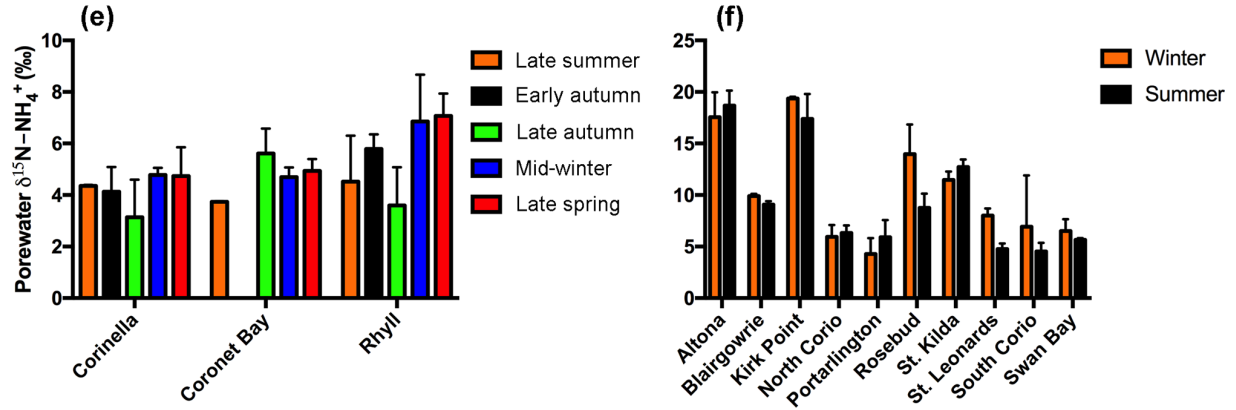

Figure 2. Porewater $\mathrm{NH}_{4}^{+}$concentrations for (a) Western Port and (b) Port Phillip Bay, seagrass root isotopic signature $\left(\delta^{15} \mathrm{~N}\right)$ for $(\mathbf{c})$ Western Port and (d) Port Phillip Bay, and porewater $\mathrm{NH}_{4}^{+}$isotopic signature for (e) Western Port and (f) Port Phillip Bay. Note: no results are available for the isotopic signature of porewater $\mathrm{NH}_{4}^{+}$in early autumn at Coronet Bay. All values are mean $\pm \mathrm{SD}$.

tion, nor $\Delta\left(\delta^{15} \mathrm{~N}_{\text {porewater }} \mathrm{NH}_{4}^{+}\right.$-sediment $)$and porewater $\mathrm{NH}_{4}^{+}$ concentration (Fig. 5).

\section{Discussion}

Overall, our study showed very close agreement between the bulk sediment $\delta^{15} \mathrm{~N}$ and the seagrass tissue $\delta^{15} \mathrm{~N}$ (Fig. 4). This finding is not surprising and is consistent with the paradigm that seagrasses rely on sediment-derived nitrogen (Barrón et al., 2006), and that a significant fraction of organic matter within seagrass sediments is derived from seagrass itself (Kennedy et al., 2010). The mineralisation of organic matter to $\mathrm{NH}_{4}^{+}$and subsequent assimilation by seagrass roots is a critical link coupling the nitrogen $\delta^{15} \mathrm{~N}$ values in these two pools. To date, there has only been one study on the ${ }^{15} \mathrm{~N} /{ }^{14} \mathrm{~N}$ ratios of porewater $\mathrm{NH}_{4}^{+}$and its relationship with ${ }^{15} \mathrm{~N} /{ }^{14} \mathrm{~N}$ ratios in bulk sediment and vegetation in coastal sediments (Papadimitriou et al., 2006). That study focused on one location in Wales over a seasonal cycle and the present study greatly extends the geographical spread of simultaneous isotope measurements of seagrass tissue, sediment and porewater. 
Table 1. Summary of possible nitrogen isotopic endmembers in Western Port and Port Phillip Bay.

\begin{tabular}{lrl}
\hline Source & $\begin{array}{c}\text { Isotopic end- } \\
\text { member (\%o) }\end{array}$ & Reference \\
\hline Port Phillip Bay & & \\
\hline Nitrogen fixation & 0.0 & Owens (1988) \\
Oceanic & 6.9 & Russell et al. (2017) \\
Yarra River & 9.7 & Hirst et al. (2016) \\
Western Treatment Plant (WTP) & 22.8 & Nicholson et al. (2011) \\
\hline Western Port & & \\
\hline Nitrogen & & \\
Oceanic & 0.0 & Owens (1988) \\
Riverine & 6.9 & Russell et al. (2017) \\
\hline
\end{tabular}

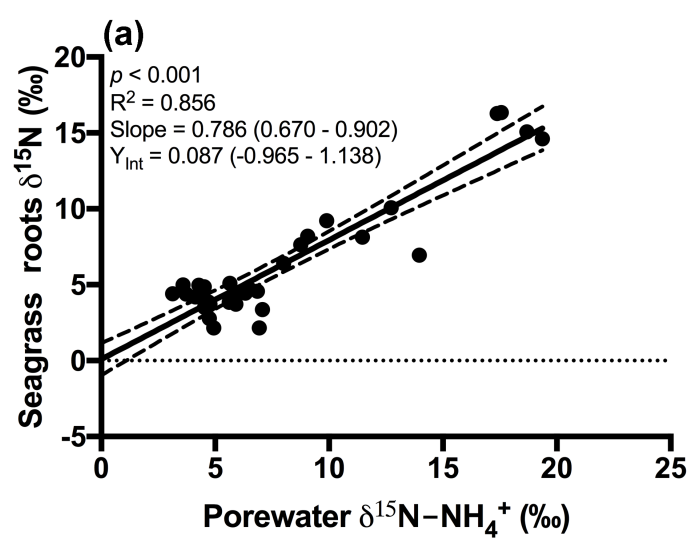

(b)

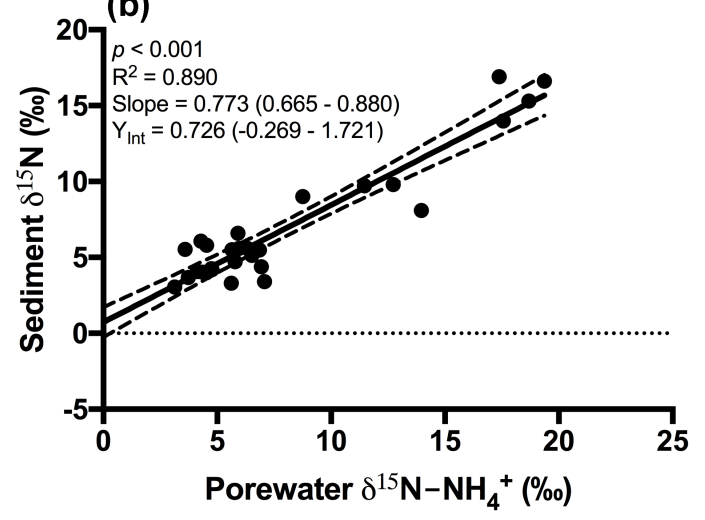

Figure 3. Plot of the porewater $\delta^{15} \mathrm{~N}-\mathrm{NH}_{4}^{+}$against (a) $\delta^{15} \mathrm{~N}$ of seagrass roots and (b) $\delta^{15} \mathrm{~N}$ of the sedimentary nitrogen pool. The $95 \%$ confidence intervals of the linear regression are depicted by the dashed lines, and the values in parentheses represent the $95 \%$ confidence interval range for the slope and $y$ intercept.

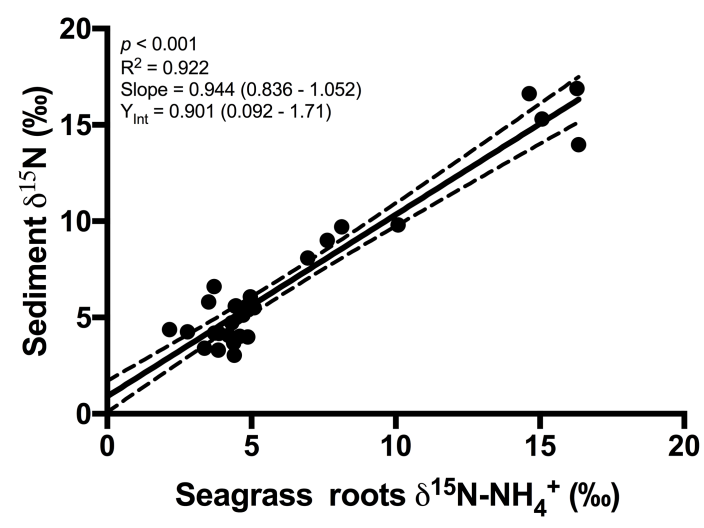

Figure 4. Plot of sediment $\delta^{15} \mathrm{~N}$ against seagrass $\delta^{15} \mathrm{~N}$.

\subsection{Isotopic signatures of the seagrass pool relative to the porewater $\mathrm{NH}_{4}^{+}$pool}

Our results showed that at low $\delta^{15} \mathrm{~N}$ values, there was typically a close agreement between the porewater $\mathrm{NH}_{4}^{+}$and seagrass isotopic signatures, but this increased to $\sim 5 \%$ at the highest $\delta^{15} \mathrm{~N}$ values. The highest $\delta^{15} \mathrm{~N}$ values were observed in the north of Port Phillip Bay which is influenced by the WTP. Given that there were generally negligible temporal changes in isotopic signature at these sites (Fig. 2f), we assume that the offsets observed here were not artefacts of lags associated with changing isotope pools over time. Three possible explanations for these offsets are considered as follows:

1. Seagrass are assimilating another source of nitrogen through their leaves. In the following discussion, we assume negligible fractionation of nitrogen during leaf assimilation from the water column. We justify this on the basis that $\mathrm{NH}_{4}^{+}$and $\mathrm{NO}_{3}^{-}$concentrations in the water column are typically $<1 \mu \mathrm{M}$ at the study sites, and therefore it is unlikely that significant fractionation will take place. 

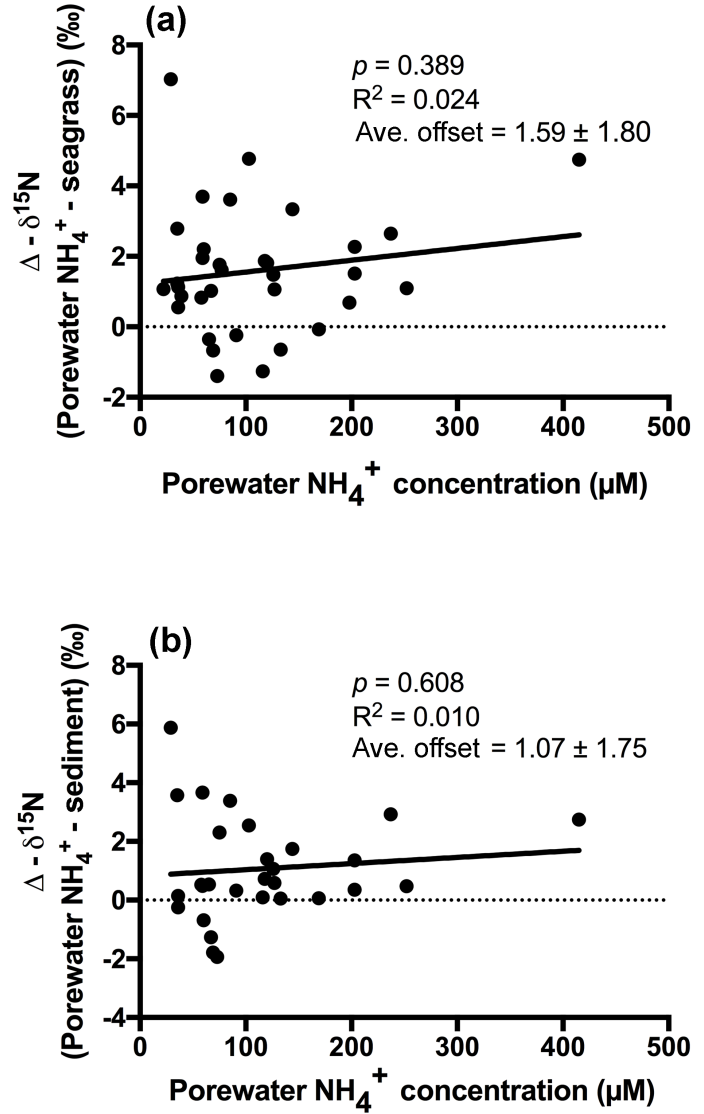

Figure 5. Plot of porewater $\mathrm{NH}_{4}^{+}$concentration against (a) the difference between the porewater $\delta^{15} \mathrm{~N}-\mathrm{NH}_{4}^{+}$and the seagrass $\delta^{15} \mathrm{~N}$ (b) the difference between the porewater $\delta^{15} \mathrm{~N}-\mathrm{NH}_{4}^{+}$and the bulk sediment $\delta^{15} \mathrm{~N}$.

If we compare the likely $\delta^{15} \mathrm{~N}$ values of nitrogen source to the seagrass at each of the sites (Table 1), they are typically higher than the porewater values. At the sites closest to the WTP (Kirk Point and Altona), the $\delta^{15} \mathrm{~N}$ of the seagrass is $\sim 15 \%$, which is $\sim 8 \%$ lighter than sewagederived DIN $(22.5 \%)$, and therefore direct assimilation of sewage derived by the seagrass leaves seems unlikely at these sites.

2. Fractionation of nitrogen during assimilation from the porewater $\mathrm{NH}_{4}^{+}$pool. Handley and Raven (1992) reported that the isotopic fractionation associated with the vegetative assimilation of $\mathrm{NH}_{4}^{+}$in a range of environments can vary from $9 \%$ to $18 \%$. Within soils, there is typically a fractionation of only $1 \% 0-2 \%$ in association with plant assimilation owing to diffusion limitation (Kendall and McDonnell, 1998; Michener and Lajtha, 2007). At first glance, the notion of diffusion limitation seems at odds with the observation that there were often high concentrations of $\mathrm{NH}_{4}^{+}$in the sediment. One possible explanation for this is that $\mathrm{NH}_{4}^{+}$concen- trations are highly heterogeneous in the sediment, resulting in very low concentrations directly within the vicinity of roots where active assimilation is occurring (Welsh et al., 1997). As such, the assimilation of $\mathrm{NH}_{4}^{+}$ from the porewater is effectively diffusion limited, leading to minimal isotope fractionation. Evidence to support this comes from the observation that there was no relationship between the $\Delta\left(\delta^{15} \mathrm{~N}_{\text {porewater }} \mathrm{NH}_{4}^{+}\right.$-seagrass $)$ and the bulk porewater $\mathrm{NH}_{4}^{+}$concentration (Fig. 5). Such a conclusion is also supported by the lack of an offset between the isotopic signature of the seagrass roots relative to that of the porewater $\mathrm{NH}_{4}^{+}$(Fig. 3a), with the $y$ intercept of this graph at $\sim 0.09 \%$. This finding is in agreement with Papadimitriou et al. (2006) who also concluded diffusion limitation was a likely explanation for the small offset observed between porewater and seagrass $\delta^{15} \mathrm{~N}$ values.

3. Nitrogen fixation within the rhizosphere. Nitrogen fixation within the rhizosphere of seagrass is well documented and it is thought to be mediated by sulfatereducing bacteria, tightly coupled to the exudation of organic carbon from seagrass roots (Welsh, 2000). As such it is possible that newly fixed nitrogen (which has a $\delta^{15} \mathrm{~N}$ of $\sim 0 \%$ ) is rapidly assimilated by seagrass rather than entering the bulk sediment pool. Under this scenario, seagrass nitrogen would become isotopically depleted compared to the porewater $\mathrm{NH}_{4}^{+}$pool. This explanation is also consistent with the increasing difference (i.e. gradient of 0.79 ) between the $\delta^{15} \mathrm{~N}$ of porewater $\mathrm{NH}_{4}^{+}$and seagrass roots at high $\delta^{15} \mathrm{~N}$ value because there is a larger difference in $\delta^{15} \mathrm{~N}$ between the nitrogen fixation and porewater $\mathrm{NH}_{4}^{+}$endmembers. This means that for a given amount of nitrogen fixation, there will be a much larger offset between the $\delta^{15} \mathrm{~N}$ of seagrass tissue and porewater $\mathrm{NH}_{4}^{+}$. Indeed if we use a simple linear mixing model (Fry, 2006) assuming a $\delta^{15} \mathrm{~N}$ for nitrogen fixation of $0 \% \mathrm{o}$ and no fractionation during assimilation, then the slope in Fig. 3a represents the proportion of nitrogen derived from the porewater, and the remainder is derived from nitrogen fixation, which is $\sim 20 \%$ in this instance. Direct measurements of nitrogen fixation in Port Phillip Bay have previously suggested nitrogen fixation contributes a maximum of $\sim 15 \%$ to nitrogen demand, with a mean of $\sim 5 \%$ (Cook et al., 2015), however, there are large uncertainties inherent in scaling instantaneous rate measurements of nitrogen fixation over the entire growth cycle of seagrass. More broadly, an estimate of $20 \%$ contribution of nitrogen fixation to seagrass nitrogen requirements is consistent with estimates of up to $30 \%$ in other systems (Cole and McGlathery, 2012; Russell et al., 2016). It is therefore plausible that nitrogen fixation accounts for the observed difference between the $\delta^{15} \mathrm{~N}$ of porewater $\mathrm{NH}_{4}^{+}$and seagrass tis- 
sue, in addition to a small but variable contribution of isotope fractionation during assimilation.

\subsection{Isotopic signatures of the sediment pool relative to the porewater $\mathrm{NH}_{4}^{+}$pool}

In general, the porewater $\mathrm{NH}_{4}^{+}$was isotopically enriched compared to the sediment pool (Figs. $3 b$ and 5b), and this enrichment was greatest at the highest $\delta^{15} \mathrm{~N}$ values (sites influenced by the WTP as discussed previously), as indicated by the slope of 0.77 in Fig. 3b. Once again this is generally consistent with previous studies of soils (Kendall and McDonnell, 1998; Michener and Lajtha, 2007) and sediment vegetated with seagrass (Papadimitriou et al., 2006). Previous work investigating the isotopic fractionation of nitrogen during mineralisation in marine sediments has found that this fractionation is generally in the range of $2 \% 0-4.5 \%$ (Lehmann et al., 2002; Möbius, 2013 and Rooze and Meile, 2016). This suggests that if mineralisation was having a dominant effect on the $\mathrm{NH}_{4}^{+}$isotope pool, then the $\delta^{15} \mathrm{~N}$ of this pool should be lower than the sediment, which was not the case in this study. Nitrification is another possible process that could lead to an enrichment of the porewater $\delta^{15} \mathrm{~N}$ pool; however, we believe it is unlikely to explain the fractionation observed here. Nitrification is an obligate aerobic process and it is generally confined to the top few millimetres of sediment owing to the limited penetration of oxygen (Rysgaard et al., 1996). Research has also found that ammonia oxidising bacteria (AOB) are generally out-competed for available $\mathrm{NH}_{4}^{+}$by a range of organisms such as macroalgae and benthic macrophytes (Risgaard-Petersen et al., 2004; Rysgaard et al., 1996). Whilst benthic primary producers such as seagrass can create micro-oxic zones deeper within the sediment (Brodersen et al., 2015; Frederiksen and Glud, 2006), these same seagrasses will also be actively competing with the nitrifiers for bioavailable nitrogen (Vonk et al., 2008). Consistent with this, we have measured negligible rates of nitrification coupled to denitrification in intact cores with ${ }^{15} \mathrm{~N}_{-} \mathrm{NH}_{4}^{+}$ tracer injected into the sediment (Russell et al., 2016).

As discussed previously, fractionation during assimilation could possibly lead to a small enrichment of the $\delta^{15} \mathrm{~N}$ of porewater $\mathrm{NH}_{4}^{+}$; however, this does not explain the increasing discrepancies between the $\delta^{15} \mathrm{~N}$ of porewater $\mathrm{NH}_{4}^{+}$and bulk sediment observed at high $\delta^{15} \mathrm{~N}$ values (as indicated by the slope of 0.77 in Fig. 3b) within the vicinity of the WTP. Another possibility is that the $\mathrm{NH}_{4}^{+}$pool within the sediment is derived from an isotopically enriched sub-pool of organic matter with a high turnover and hence release of $\mathrm{NH}_{4}^{+}$. We speculate that isotopically enriched phytoplankton and macroalgae which have assimilated nitrogen from the WTP enter the sediment pool and are rapidly turned over. This leads to an enrichment of the $\mathrm{NH}_{4}^{+}$pool compared to the bulk nitrogen pool, which is probably associated with more recalcitrant and isotopically depleted seagrass organic matter. The plausibility of this hypothesis is supported by the $\delta^{15} \mathrm{~N}$ signatures of macroalgae previously reported in Port Phillip Bay, which were $\sim 2.5 \%$ o higher than adjacent seagrass (Cook et al., 2015). Furthermore, the bulk sediment $\delta^{13} \mathrm{C}$ values of $\sim-17 \%$ o from the sites within the vicinity of the WTP suggest the organic matter within the sediment is a $\sim 50 \%$ mix of algal material $\left(\delta^{13} \mathrm{C} \sim-23 \%\right.$ ) and seagrass $\left(\delta^{13} \mathrm{C} \sim-11 \%\right.$, Cook et al., 2015). This is also consistent with the slight enrichment of the bulk sediment above seagrass in Port Phillip Bay by $\sim 1 \%$, reflecting the $50: 50 \mathrm{mix}$ between seagrass-derived organic matter and algal material enriched by a $\delta^{15} \mathrm{~N}$ of $2.5 \%$. If this algal material were to undergo degradation at a rate much higher than seagrass material, then it is quite conceivable that the $\delta^{15} \mathrm{~N}$ of the porewater will become enriched towards the algal $\delta^{15} \mathrm{~N}$, which can be as high as $20 \%$ in the vicinity of the WTP (Cook et al., 2015).

\section{Conclusions}

The strong relationships among the $\delta^{15} \mathrm{~N}$ values of the seagrass roots, porewater $\mathrm{NH}_{4}^{+}$and sediment support the current paradigm that nitrogen is tightly recycled within seagrass beds. However, the slight offset between $\delta^{15} \mathrm{~N}$ of sediment and porewater $\mathrm{NH}_{4}^{+}$, particularly in the vicinity of the WTP, also suggests that mineralisation of the isotopically enriched macroalgae could be a potential external source of nitrogen to the porewater $\mathrm{NH}_{4}^{+}$pool. The gradient of $\delta^{15} \mathrm{~N}$ of porewater $\mathrm{NH}_{4}^{+}$vs. seagrass suggests that porewater $\mathrm{NH}_{4}^{+}$is likely to contribute up to $80 \%$ of the nitrogen acquired by seagrasses in both Port Phillip Bay and Western Port, while nitrogen fixation is accounted for the remainder $20 \%$. Our study shows that simultaneous investigations of $\delta^{15} \mathrm{~N}$ of porewater $\mathrm{NH}_{4}^{+}$, bulk sediment and seagrass support three key paradigms in seagrass nitrogen acquisition: (1) seagrasses obtain the majority of their nitrogen from the sediment; (2) a small but significant proportion of this demand $(\sim 20 \%)$ can be met by nitrogen fixation; and (3) algal inputs to the sediment represent a significant source of nitrogen that is ultimately assimilated by seagrass.

Data availability. The data related to this article is available online at https://doi.org/10.26180/5bf32ead03030 (Russell et al., 2018).

Supplement. The supplement related to this article is available online at: https://doi.org/10.5194/bg-15-7225-2018-supplement.

Author contributions. All authors contributed to the design, undertaking the experiments, data interpretation and paper preparation.

Competing interests. The authors declare that they have no conflict of interest. 
Acknowledgements. The authors wish to thank Keryn Roberts for the helpful discussions regarding the application of the ammonium diffusion method used in this study, and to Adam Kessler, Caitlyn McNaughton and David Brehm for their assistance in the field. This work has been funded by the Australian Research Council (LP130100684), Melbourne Water, Parks Victoria and the Victorian Environmental Protection Authority. Douglas Russell was supported by an Australian Government Research Training Program Scholarship (RTP).

Edited by: David Gillikin

Reviewed by: two anonymous referees

\section{References}

Altabet, M. A. and Francois, R.: Sedimentary nitrogen isotopic ratio as a recorder for surface ocean nitrate utilization, Global Biogeochem. Сy., 8, 103-116, https://doi.org/10.1029/93GB03396, 1994.

APHA: Standard methods for the examination of water and wastewater, American Public Health Association, American Water Works Association, and Water Environment Federation, Washington, DC, 2005.

Barrón, C., Middelburg, J. J., and Duarte, C. M.: Phytoplankton trapped within seagrass (Posidonia oceanica) sediments are a nitrogen source: An in situ isotope labeling experiment, Limnol. Oceanogr., 51, 1648-1653, https://doi.org/10.4319/lo.2006.51.4.1648, 2006.

Brodersen, K. E., Nielsen, D. A., Ralph, P. J., and Kühl, M.: Oxic microshield and local $\mathrm{pH}$ enhancement protects Zostera muelleri from sediment derived hydrogen sulphide, New Phytol., 205, 1264-1276, https://doi.org/10.1111/nph.13124, 2015.

Brooks, P. D., Stark, J. M., McInteer, B. B., and Preston, T.: Diffusion Method To Prepare Soil Extracts For Automated Nitrogen-15 Analysis, Soil Sci. Soc. Am. J., 53, 1707-1711, https://doi.org/10.2136/sssaj1989.03615995005300060016x, 1989.

Christiaen, B., Bernard, R. J., Mortazavi, B., Cebrian, J., and Ortmann, A. C.: The degree of urbanization across the globe is not reflected in the $\delta^{15} \mathrm{~N}$ of seagrass leaves, Mar. Pollut. Bull., 83, 440-445, https://doi.org/10.1016/j.marpolbul.2013.06.024, 2014.

Cole, L. W. and McGlathery, K. J.: Nitrogen fixation in restored eelgrass meadows, Mar. Ecol.-Prog. Ser., 448, 235-246, https://doi.org/10.3354/meps09512, 2012.

Cook, P. L. M., Evrard, V., and Woodland, R. J.: Factors controlling nitrogen fixation in temperate seagrass beds, Mar. Ecol.-Prog. Ser., 525, 41-51, https://doi.org/10.3354/meps11247, 2015.

Frederiksen, M. S. and Glud, R. N.: Oxygen dynamics in the rhizosphere of Zostera marina: A two-dimensional planar optode study, Limnol. Oceanogr., 51, 1072-1083, https://doi.org/10.4319/1o.2006.51.2.1072, 2006.

Freudenthal, T., Wagner, T., Wenzhöfer, F., Zabel, M., and Wefer, G.: Early diagenesis of organic matter from sediments of the Eastern subtropical Atlantic: Evidence from stable nitrogen and carbon isotopes, Geochim. Cosmochim. Acta, 65, 1795-1808, https://doi.org/10.1016/S0016-7037(01)00554-3, 2001.

Fry, B.: Stable Isotope Ecology, Springer, New York, 2006.
Handley, L. L. and Raven, J. A.: The use of natural abundance of nitrogen isotopes in plant physiology and ecology, Plant, Cell Environ., 15, 965-985, https://doi.org/10.1111/j.13653040.1992.tb01650.x, 1992.

Harris, G., Batley, G., Fox, D., Hall, D., Jernakoff, P., Molloy, R., Murray, A., Newell, B., Parslow, J., and Skyring, G.: Port Phillip Bay Environmental Study Final Report, CSIRO, Canberra, Australia, 1996.

Hirst, A. J., Longmore, A. R., Ball, D., Cook, P. L. M., and Jenkins, G. P.: Linking nitrogen sources utilised by seagrass in a temperate marine embayment to patterns of seagrass change during drought, Mar. Ecol.-Prog. Ser., 549, 79-88, https://doi.org/10.3354/meps11708, 2016.

Holmes, R. M., McClelland, J. W., Sigman, D. M., Fry, B., and Peterson, B. J.: Measuring 15N-NH4+ in marine, estuarine and fresh waters: An adaptation of the ammonia diffusion method for samples with low ammonium concentrations, Mar. Chem., 60, 235-243, https://doi.org/10.1016/S0304-4203(97)00099-6, 1998.

Kendall, C. and McDonnell, J. J. (Eds.): Isotope Tracers in Catchment Hydrology, Elsevier, Amsterdam, 1998.

Kennedy, H., Beggins, J., Duarte, C. M., Fourqurean, J. W., Holmer, M., Marbà, N., and Middelburg, J. J.: Seagrass sediments as a global carbon sink: Isotopic constraints, Global Biogeochem. Cy., 24, https://doi.org/10.1029/2010GB003848, 2010.

Larkum, A. W. D., Orth, R. J., and Duarte, C. M. (Eds.): Seagrasses: biology, ecology and conservation, Springer, The Netherlands, 2006.

Lehmann, M. F., Bernasconi, S. M., Barbieri, A., and McKenzie, J. A.: Preservation of organic matter and alteration of its carbon and nitrogen isotope composition during simulated and in situ early sedimentary diagenesis, Geochim. Cosmochim. Ac., 66, 35733584, https://doi.org/10.1016/S0016-7037(02)00968-7, 2002.

McClelland, J. W. and Valiela, I.: Linking nitrogen in estuarine producers to land derived sources, Limnol. Oceanogr., 43, 577-585, https://doi.org/10.4319/lo.1998.43.4.0577, 1998.

McGlathery, K. J., Berg, P., and Marino, R.: Using porewater profiles to assess nutrient availability in seagrassvegetated carbonate sediments, Biogeochemistry, 56, 239-263, https://doi.org/10.1023/A:1013129811827, 2001.

McKee, K. L., Feller, I. C., Popp, M., and Wanek, W.: Mangrove isotopic $\left(\delta^{15} \mathrm{~N}\right.$ and $\left.\delta^{13} \mathrm{C}\right)$ fractionation across a nitrogen vs. phosphorous limitation gradient, Ecology, 83, 1065-1075, https://doi.org/10.1890/00129658(2002)083[1065:MINACF]2.0.CO;2, 2002.

Michener, R. and Lajtha, K. (Eds.): Stable isotopes in Ecology and Environmental Science, Blackwell Publishing Malden, 2007.

Mobius, J.: Isotope fractionation during nitrogen remineralization (ammonification): Implications for nitrogen isotope biogeochemistry, Geochim. Cosmochim. Ac., 105, 422-432, https://doi.org/10.1016/j.gca.2012.11.048, 2013.

Nicholson, G., Longmore, A., and Spooner, D.: Assessment of the impact of effluent from the Western Treatment Plant on trace metals in sentinel organisms and sediment, Fisheries Victoria Internal Report No. 32, Victorian Department of Primary Industries, Queenscliff, 2011.

Nielsen, S. L., Banta, G. T., and Pedersen, M. F. (Eds.): Estuarine nutrient cycling: The influence of primary producers, Kluwer, Dordrecht, 2004. 
Owens, N. J. P.: Natural variations in $15 \mathrm{~N}$ in the marine environment, Adv. Mar. Biol., 24, 389-451, https://doi.org/10.1016/S0065-2881(08)60077-2, 1988.

Papadimitriou, S., Kennedy, H., Rodrigues, R. M. N. V., Kennedy, D. P., and Heaton, T. H. E.: Using variation in the chemical and stable isotopic composition of Zostera noltii to assess nutrient dynamics in a temperate seagrass meadow, Org. Geochem., 37, 1343-1358, https://doi.org/10.1016/j.orggeochem.2006.01.007, 2006.

Papadimitriou, S., Kennedy, H., Kennedy, D., Duarte, C. M., and Marbà, N.: Sources of organic matter in seagrasscolonized sediments: A stable isotope study of the silt and clay fraction from Posidonia oceanica meadows in the western Mediterranean, Org. Geochem., 36, 949-961, https://doi.org/10.1016/j.orggeochem.2004.12.002, 2005.

Prokopenko, M. G., Hammond, D. E., Berelson, W. M., Bernhard, J. M., Stott, L., and Douglas, R.: Nitrogen cycling in the sediments of Santa Barbara basin and Eastern Subtropical North Pacific: nitrogen isotopes, diagenesis and possible chemosymbiosis between two lithotrophs (Thioploca and Anammox) "riding on a glider", Earth Planet. Sc. Lett., 242, 186-204, https://doi.org/10.1016/j.eps1.2005.11.044, 2006.

Risgaard-Petersen, N., Nicolaisen, M. H., Revsbech, N. P., and Lomstein, B. A.: Competition between Ammonia-Oxidizing Bacteria and Benthic Microalgae, Appl. Environ. Microb., 70, 5528-5537, https://doi.org/10.1128/AEM.70.9.5528-5537.2004, 2004.

Rooze, J. and Meile, C.: The effect of redox conditions and bioirrigation on nitrogen isotope fractionation in marine sediments, Geochim. Cosmochim. Ac., 184, 227-239, https://doi.org/10.1016/j.gca.2016.04.040, 2016.

Russell, D. G., Kessler, A. J., Wong, W. W., and Cook, P. L. M.: The importance of nitrogen fixation to a temperate, intertidal embayment determined using a stable isotope mass balance approach, Biogeosciences Discuss., https://doi.org/10.5194/bg2017-418, 2017.
Russell, D. G., Warry, F. Y., and Cook, P. L. M.: The balance between nitrogen fixation and denitrification on vegetated and nonvegetated intertidal sediments, Limnol. Oceanogr., 61, 20582075, https://doi.org/10.1002/lno.10353, 2016.

Russell, D. G., Wong, W. W., and Cook, P. L. M.: Raw data Biogeosciences seagrass, 8, 44, available at: https://doi.org/10.26180/5bf32ead03030, last access: 20 November 2018 .

Rysgaard, S., Risgaard-Petersen, N., and Sloth, N. P.: Nitrification, denitrification, and nitrate ammonification in sediments of two coastal lagoons in Southern France, in: Coastal Lagoon Eutrophication and Anaerobic Processes (CLEAN), Springer, 1996.

Sachs, J. P. and Repeta, D. J.: Oligotrophy and nitrogen fixation during eastern Mediterranean sapropel events, Science, 286, 24852488, https://doi.org/10.1126/science.286.5449.2485, 1999.

Saino, T. and Hattori, A.: Geographical variation of the water column distribution of suspended particulate organic nitrogen and its ${ }^{15} \mathrm{~N}$ natural abundance in the Pacific and its marginal seas, Deep-Sea Res. Pt. A, 34, 807-827, https://doi.org/10.1016/01980149(87)90038-0, 1987.

Vonk, J. A., Middelburg, J. J., Stapel, J., and Bouma, T. J.: Dissolved organic nitrogen uptake by seagrasses, Limnol. Oceanogr., 53, 542-548, https://doi.org/10.4319/lo.2008.53.2.0542, 2008.

Waycott, M., Duarte, C. M., Carruthers, T. J. B., Orth, R. J., Dennison, W. C., Olyarnik, S., Calladine, A., Fourqurean, J. W., Heck, K. L., and Hughes, A. R.: Accelerating loss of seagrasses across the globe threatens coastal ecosystems, P. Natl. Acad. Sci. USA, 106, 12377-12381, https://doi.org/10.1073/pnas.0905620106, 2009.

Welsh, D. T.: Nitrogen fixation in seagrass meadows: Regulation, plant-bacteria interactions and significance to primary productivity, Ecol. Lett., 3, 58-71, https://doi.org/10.1046/j.14610248.2000.00111.x, 2000.

Welsh, D. T., Bourgues, S., de Wit, R., and Auby, I.: Effect of plant photosynthesis, carbon sources and ammonium availability on nitrogen fixation rates in the rhizosphere of Zostera noltii, Aquat. Microb. Ecol., 12, 285-290, https://doi.org/10.3354/ame012285, 1997. 